\title{
Arrhythmogenic right ventricular cardiomyopathy: an overview and update
}

\author{
Adriana Grigoraș ${ }^{1,2}$, Laura Adriana Knieling ${ }^{1,2}$, Cornelia Amălinei ${ }^{\star 1,2}$ \\ 1Department of Morphofunctional Sciences I, "Grigore T. Popa" University of Medicine and Pharmacy, \\ lasi, Romania, ${ }^{2}$ Institute of Legal Medicine lasi, Romania
}

\begin{abstract}
Arrhythmogenic right ventricular cardiomyopathy consists in partial or total progressive replacement of cardiac muscle fibers with a fibro-adipose tissue. This is a hereditary disease with an autosomal dominant inheritance with incomplete penetrance and variable expressivity, except two autosomal recessive syndromes. The most frequent abnormal proteins are that of desmosomal intercellular junctions, such as junctional plakoglobin, plakophilin-2, desmoplakin, desmoglein-2, and desmocollin-2, although other types of nondesmosomal components may be also involved. Desmosomal disorders result in myocardial fibers necrosis and their progressive replacement with fibro-adipose tissue. The morphological modifications are usually beginning in the subepicardial layer and develop towards the endocardium, being associated with the ventricular wall degeneration, thinning, and progressive increase of the amount of adipose tissue. The average age of clinical manifestations onset is around 30-40 years old, with ventricular arrhythmia and high risk of sudden death. Currently, the diagnosis is based on the 2010 Task Force Diagnostic criteria. The current review presents an overview on traditional knowledge about this disease, adding updated information regarding molecular and genetic data. The knowledge of this disease is important for medical practice as a possible cause of arrhythmia and sudden death and its prognosis might be improved by appropiate genetic testing as family screening.
\end{abstract}

Keywords: ventricular arrhythmias, cardiomyopathy, dysplasia

\section{Introduction}

Arrhythmogenic right ventricular cardiomyopathy is a rare primary myocardial disease that is clinically characterized by lifethreatening ventricular arrhythmias secondary to fibrofatty replacement of the right ventricular myocardium.

Although genetic factor plays a major role in disease determinism, the modifications are not manifested at birth.

The term "arrhythmogenic right ventricular

Received: March 2017; Accepted after review: May 2017; Published: June 2017.

${ }^{*}$ Corresponding author: Cornelia Amalinei, MD, $\mathrm{PhD}$, Department of Morphofunctional Sciences I, "Grigore T. Popa" University of Medicine and Pharmacy, 16, Universitatii Street, 700115, Iasi, Romania.

E-mail: cornelia.amalinei@umfiasi.ro cardiomyopathy" (ARVC) is mostly agreed, replacing the previous name of "arrhythmogenic right ventricular dysplasia" (ARVD), still in use. A special mention should be made regarding the possibility of process extension from the right ventricle to the interventricular septum or even to the left ventricle [1].

The current term of "arrhythmogenic right ventricular cardiomyopathy" is more appropriate than ARVD, considering that the disease is not manifested at birth but its onset is later, during adult life.

\section{History}

In 1905, Osler described a particular lesion characterized by thin ventricles ("parchmentlike"), as a necroptic finding in a young man, apparently healthy, deceased 
following a medium intensity physical activity [2].

In 1952, similar gross finding of the right ventricle was observed in a congenital disease named Uhl's anomaly [3].

In 1977, the term "arrhythmogenic right ventricular dysplasia" was introduced, being based on an abnormal development of the ventricular wall, similar to that seen in Uhl's anomaly $[4,5]$.

In 1986, Protonotarios Nikos, a cardiologist, reported a familial cardiac disease associated with a cutaneous syndrome [6], being named according to the Greek island of origin (Naxos disease) and later on another syndrome has been described, as Carvajal syndrome [7], both having a recessive transmission in descendants.

The term of "dysplasia" has been replaced by the designation of "cardiomyopathy" and the main diagnosis features have been set [8], as the task force criteria, with later modifications [9].

\section{Brief update on myocardial fibers desmosomes}

The myocardial cells are disposed in columns, being kept together by specialized junctions, named intercalated discs. These junctions comprise cell-to-cell adhesion junctions composed of fascia adherens, gap junctions, and maculae adherentes (desmosomes). Desmosomes reinforce the fascia adherens and are parts of both transverse and lateral components of the intercalated discs [10].

The desmosomes mediate direct cell-tocell contact by providing anchoring sites for intermediate filaments, being necessary for electrical conduction, mechanical contraction [11], participating also in tissue morphogenesis and differentiation [12]. In the area of the macula adherens, desmogleins and desmocollins provide the linkage between the plasma membranes of adjacent cells.

Electron microscopy reveals on the cytoplasmic side of the plasma membrane of each of the adjoining cells a disc-shaped structure consisting of very dense material called the desmosomal attachment plaque.
This structure measures about $400 \mathrm{~nm} \times 250$ $\mathrm{nm} \times 10 \mathrm{~nm}$ and anchors intermediate filaments [13]. The filaments appear to loop through the attachment plaques and extend back out into the cytoplasm. They are thought to play a role in dissipating physical forces throughout the cell, by their attachment to the intermediate filaments. In myocardial fibers, each attachment plaque is composed of five constitutive proteins, junctional plakoglobin, plakophilin-2, desmoplakin, desmoglein-2, and desmocollin-2. Their encoding genes have been identified (Table 1) [11].

The intercellular space of the macula adherens is up to $30 \mathrm{~nm}$ and is occupied by a dense medial band, the intermediate line. This line represents extracellular portions of the transmembrane glycoproteins, the desmogleins and desmocollins, which are members of the cadherin family of $\mathrm{Ca}^{2+}$ dependent cell adhesion molecules. In the presence of $\mathrm{Ca}^{2+}$, extracellular portions of desmogleins and desmocollins bind adjacent identical molecules of neighboring cells (homotypic binding), forming a "cadherin zipper", identified in X-ray crystallographic studies. The cytoplasmic portions of desmogleins and desmocollins are integral components of the desmosomal attachment plaque. They interact with plakoglobin, desmoplakin, and plakophilin that are involved in desmosome assembly and the anchoring of intermediate filaments of desmin [10].

\section{Etiology and epidemiology}

ARVC consists in partial or total progressive replacement of cardiac muscle fibers with a fibro-adipose tissue, beginning from the epicardial surface towards the endocardium. In the advanced stages of the disease, the right ventricular wall becomes extremely thin, with endocardium-epicardium apposition [12].

ARVC prevalence in general population is variable, with ranges from 1:2 000 to 1: 5000 , with a special mention that some of these values may be even larger [13]. ARVC represents $2-5 \%$ of cases of young people sudden death, in Europe [14, 15].

According to the results of a retrospective study performed on 200 persons with sudden 
death, the cause has been microscopically detected as ARVC, in $10.4 \%$ of cases [16].

As confirmed by our experience [17], males are more frequently affected compared to females, the rate between men: women being approximately $3: 1$ [18]. The disease is usually manifested in the second-fifth decades of life, as palpitations, syncope, and sudden death [19]. The symptoms are extremely rare under 12 years old or more than 60 years old age [20], and cardiac failure is extremely rare, manifested during late progression of the disease. An exemplifying result has been provided by a study performed on 439 patients, 36 \pm 14 years old age, revealing a specific symptomatology in 419 patients $(95 \%)$, only 20 of them being asymptomatic [21].

\section{Genetic syndromes and pathogeny}

Genetic mutations have been identified in approximately $60 \%$ of patients [20]. The majority of cases have AD (autosomal dominant) transmission, with variable penetrance, although a minority of cases represents a manifestation of cardiocutaneous syndrome with AR (autosomal recessive) transmission, such as Naxos or Carvajal syndromes [22].

Naxos syndrome is correlated with a homozygous deletion of two base pairs found in the plakoglobin gene located in the 17q21.2 locus (Table 1) [11, 23].

ARVC in Carvajal syndrome is associated with woolly hair and palmoplantar keratodermia, as a consequence of homozygous DSP mutations in the desmoplakin gene located in the 6 p24.3 locus (Table 1) [11, 24].

Although the literature considers ARVC as a genetic disease involving intercellular junctions of desmosomal-type [19, 25], there are other causative genes.

Currently, 16 mutations have been described in ARVC (Table 1), six of them being associated with desmosomal-type junctional complexes from the intercalated disks [11, 26, 27]. Relatively recent studies have revealed that approximately $50-60 \%$ of patients with ARVC have a mutated gene encoding a desmosomal protein [28-30]. Occasionally, multiple mutations have been identified in the same patient [31].

Other types of mutations characteristic for ARVC are seen in atypical types of disease, involving non-desmosomal proteins, such as desmin (DES), transmembrane protein 43 (TMEM43), lamin-A/C (LMNA), titin (TTN), phospholamban (PLN), and $\alpha$-T-catenin (CTNNA3) [11, 20, 32].

A rare type of disease has been identified in 1994, involving only several families, named ARVC type 1 , determined by transforming growth factor $\beta-3$ (TGF $\beta 3$ ) mutations [33, 34], manifested as myocardial fibrosis, as a result of increased TGFB3 expression [11].

The pathogenic mechanism is not completely elucidated but two theories are currently under debate, namely the degeneration-inflammation model and the transdifferentiation model [1], as possible pathways of structural alterations of the right ventricular wall in ARVC.

According to the degenerationinflammation model of pathogenesis, the alteration of myocardial intercellular adhesion results in a diminished stress resistance of cardiac muscle fibers and the most susceptible fibers are those located in the right ventricle. The necrosis and inflammation are followed by fibrosis and infiltration with adipose tissue, as a non-specific local response, analogous to the process taking place in other myocardial diseases [35].

The local inflammation, mainly expressed by accumulation of neutrophils and lymphocytes, has been described by Basso, in 1996, and has been also identified by other researchers, especially in severe types of ARVC [36, 37].

The pathogenic mechanism is not completely elucidated but two theories are currently under debate, namely the degeneration-inflammation model and the transdifferentiation model [1], as possible pathways of structural alterations of the right ventricular wall in ARVC. 
Table 1. Genetic syndromes manifested by ARVC

\begin{tabular}{|c|c|c|c|c|c|c|}
\hline Genotype & $\begin{array}{l}\text { Genetic } \\
\text { syndrome or } \\
\text { other diseases }\end{array}$ & $\begin{array}{l}\text { Genetic } \\
\text { mutation }\end{array}$ & Location & Mutated proteins & $\begin{array}{l}\text { Transmi } \\
\text { ssion } \\
\text { type }\end{array}$ & $\begin{array}{l}\text { Mutated proteins } \\
\text { location or } \\
\text { function }\end{array}$ \\
\hline ARVC12 & Naxos & JUP & $17 q 21.2$ & plakoglobin & AR & Desmosome \\
\hline ARVC8 & $\begin{array}{l}\text { Carvajal } \\
\text { (DCM with wooly } \\
\text { hair and } \\
\text { keratoderma) }\end{array}$ & DSP & $6 p 24.3$ & desmoplakin & AR & Desmosome \\
\hline ARVC1 & - & TGFB3 & $14 q 24.3$ & $\begin{array}{l}\text { transforming } \\
\text { growth factor } \beta-3\end{array}$ & $A D$ & Myocardial fibrosis \\
\hline \multirow[t]{2}{*}{ ARVC2 } & DCM & \multirow[t]{2}{*}{ RYR2 } & \multirow[t]{2}{*}{$1 q 43$} & \multirow{2}{*}{$\begin{array}{l}\text { cardiac ryanodine } \\
\text { receptor }\end{array}$} & \multirow[t]{2}{*}{$A D$} & \multirow{2}{*}{$\begin{array}{l}\text { Sarcoplasmic } \\
\text { reticulum; cardiac } \\
\text { contraction }\end{array}$} \\
\hline & CPVT & & & & & \\
\hline ARVC3 & - & unknown & $\begin{array}{l}14 q 12- \\
q 22\end{array}$ & NA & $A D$ & Desmosome \\
\hline \multirow[t]{2}{*}{ ARVC4 } & $\mathrm{HCM}$ & \multirow[t]{2}{*}{ TTN } & \multirow{2}{*}{$\begin{array}{l}\text { 2q32.1- } \\
\text { q32.3 }\end{array}$} & \multirow[t]{2}{*}{ titin } & \multirow[t]{2}{*}{$A D$} & \multirow{2}{*}{$\begin{array}{l}\text { Passive restoring } \\
\text { force of the } \\
\text { sarcomere }\end{array}$} \\
\hline & DCM & & & & & \\
\hline ARVC5 & $\begin{array}{l}\text { EDMD } \\
\text { RV aneurysm }\end{array}$ & TMEM43 & $3 p 25.1$ & $\begin{array}{l}\text { transmembrane } \\
\text { protein } 43\end{array}$ & $A D$ & $\begin{array}{l}\text { Nuclear membrane } \\
\text { organizer }\end{array}$ \\
\hline ARVC6 & - & unknown & $\begin{array}{l}\text { 10p14- } \\
\text { p12 }\end{array}$ & NA & $A D$ & NA \\
\hline \multirow[t]{2}{*}{ ARVC7 } & Myopathy & \multirow[t]{2}{*}{ DES } & \multirow[t]{2}{*}{$2 q 35$} & \multirow[t]{2}{*}{ desmin } & \multirow[t]{2}{*}{$A D$} & \multirow{2}{*}{$\begin{array}{l}\text { Intermediate } \\
\text { filament }\end{array}$} \\
\hline & Cardiomyopathy & & & & & \\
\hline ARVC9 & - & PKP2 & $12 \mathrm{p} 11$ & plakophilin-2 & $A D$ & Desmosome \\
\hline ARVC10 & - & DSG2 & $18 q 12.1$ & cadherin-like & $A D$ & Desmosome \\
\hline ARVC11 & - & DSC2 & $18 q 12.1$ & $\begin{array}{l}\text { transmembrane } \\
\text { glycoproteins }\end{array}$ & $A D$ & Desmosome \\
\hline \multirow{9}{*}{ Others } & DCM & PLN & $6 q 22.1$ & phospholamban & $A D$ & $\begin{array}{l}\text { Calcium handling in } \\
\text { myocardium } \\
\text { contractions }\end{array}$ \\
\hline & EDMD & \multirow{3}{*}{ LMNA } & \multirow{3}{*}{$1 q 22$} & \multirow{3}{*}{ lamin $A / C$} & \multirow{3}{*}{$A D$} & \multirow{3}{*}{$\begin{array}{l}\text { Lining of the } \\
\text { nuclear membrane; } \\
\text { cells stabilization }\end{array}$} \\
\hline & $\begin{array}{l}\text { Premature aging } \\
\text { syndrome }\end{array}$ & & & & & \\
\hline & $\begin{array}{l}\text { DCM with sinus } \\
\text { bradycardia and } \\
\text { conduction } \\
\text { disturbance }\end{array}$ & & & & & \\
\hline & $\begin{array}{l}\text { Long QT } \\
\text { syndrome type } 3\end{array}$ & \multirow[t]{4}{*}{ SCN5A } & \multirow[t]{4}{*}{$3 p 21$} & \multirow[t]{4}{*}{$\begin{array}{l}\text { cardiac sodium } \\
\text { channel }\end{array}$} & \multirow[t]{4}{*}{$A D$} & \multirow{4}{*}{$\begin{array}{l}\text { Rapid structural } \\
\text { changes as } \\
\text { response to } \\
\text { myocardium } \\
\text { electrical field }\end{array}$} \\
\hline & $\begin{array}{l}\text { Brugada } \\
\text { syndrome }\end{array}$ & & & & & \\
\hline & $\begin{array}{l}\text { Progressive } \\
\text { cardiac } \\
\text { conduction } \\
\text { disease }\end{array}$ & & & & & \\
\hline & $\mathrm{DCM}$ & & & & & \\
\hline & - & CTNNA3 & $10 q 22.2$ & alpha-T catenin & $A D$ & $\begin{array}{l}\text { Binds to plakophilin; } \\
\text { intercellular } \\
\text { adhesion }\end{array}$ \\
\hline
\end{tabular}

Dilated cardiomyopathy (DCM); Catecholaminergic polymorphic ventricular tachycardia (CPVT); Hypertrophic cardiomyopathy (HCM); Emery-Dreifuss muscle dystrophy (EDMD), Not available (NA) 
The pathogenic mechanism is not completely elucidated but two theories are currently under debate, namely the degeneration-inflammation model and the transdifferentiation model [1], as possible pathways of structural alterations of the right ventricular wall in ARVC.

According to the degenerationinflammation model of pathogenesis, the alteration of myocardial intercellular adhesion results in a diminished stress resistance of cardiac muscle fibers and the most susceptible fibers are those located in the right ventricle. The necrosis and inflammation are followed by fibrosis and infiltration with adipose tissue, as a non-specific local response, analogous to the process taking place in other myocardial diseases [35].

The local inflammation, mainly expressed by accumulation of neutrophils and lymphocytes, has been described by Basso, in 1996, and has been also identified by other researchers, especially in severe types of ARVC [36, 37].

Mononuclear infiltration occurrence in myocardium may also be the result of a viral infection, but viral myocarditis is not considered as an etiologic factor of ARVC [38]. The involvement of viral infections in ARVC pathogeny cannot be completely excluded, as they induce variable degrees of myocardial cells apoptosis, facilitated by genetic predisposition [31, 39].

As a consequence, it is still debated if the inflammation associated or not with viral infections with myocardial tropism is a direct cause or only a secondary manifestation of myocytary lesions characteristic for ARVC. Another plausible hypothesis is that local proinflammatory mediators may interfere with the integrity and desmosomal activity of the intercalated disks, considering their ability of plakoglobin redistribution or TGF $\beta 3$ overexpression [36, 37]. In a transdifferentiation model, desmosomes are able to contribue to the mediation of some intercellular signals, via Wnt/ $\beta$-catenin pathway, being negatively regulated by plakoglobin by nuclear competition with $\beta$ catenin [40]. This perturbation of the intercellular signals induces cardiac cells apoptosis and their replacement with fibroadipose tissue.

Arrhythmias are probably the result of gap junctions remodeling in intercalated disks and sodium flux downregulation, due to interrelationships between desmosomes, gap junctions, and voltage-gated sodium channels [41].

It is also plausible that the two mentioned mechanisms are intricated, as more as ARVC is currently considered a disease of the intercalated disk, as a carrefour of desmosomal and non-desmosomal close interactions [31, 41].

\section{Gross findings and histopathology}

The morphologic characteristic of ARVC is the progressive replacement of right ventricle myocytes with fibro-adipose tissue (Figures 1$3)$. This process is initiated in subepicardial layers and progresses toward endocardium, in a different manner when compared to ischemic cardiomyopathy, resulting in ventricular wall thinning [42]. The replacement of myocardium with fibro-adipose tissue may be parcelar or diffuse [17]. In evolution, apex, infundibulum or posterior-inferior ventricular wall saccular aneurysms may occur. In late stages, the ventricular wall is extremely thin, with epicardial apposition on endocardium, termed as "papyraceous right ventricle" [26].

Having this classic description as a start point, necropsic studies have revealed a fibroadipose infiltration of the left ventricle wall or, exceptionally, of the ventricular septae in patients with ARVC [1]. In rare circumstances, there are parcelar gross findings and consequently the diagnosis is only microscopical [43], as confirmed in our practical experience.

Trichromic staining may evidentiate discrete areas of fibrosis and the remodeling of intercellular intercalated disks is evident in electron microscopy [1].

Immunohistochemical study of the desmosomal proteins is not a useful method in diagnosis as the same lesional feature may be also described in other myocardial lesions, such as sarcoidosis or giant cells myocarditis $[36,44]$. 


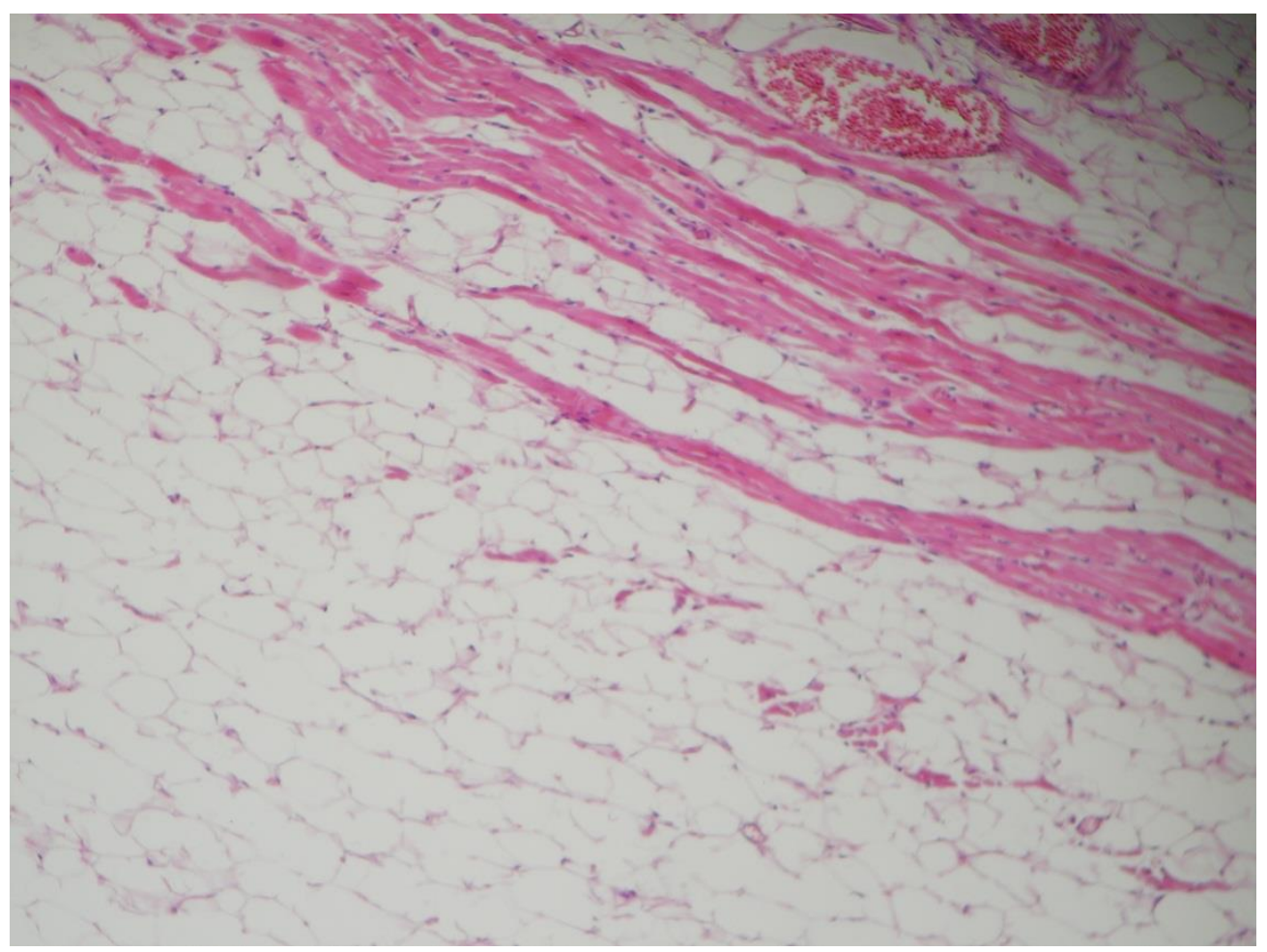

Fig. 1. Myocardium appearance in ARVC with important decrease in cardiomyocytes number (HE, 40x)

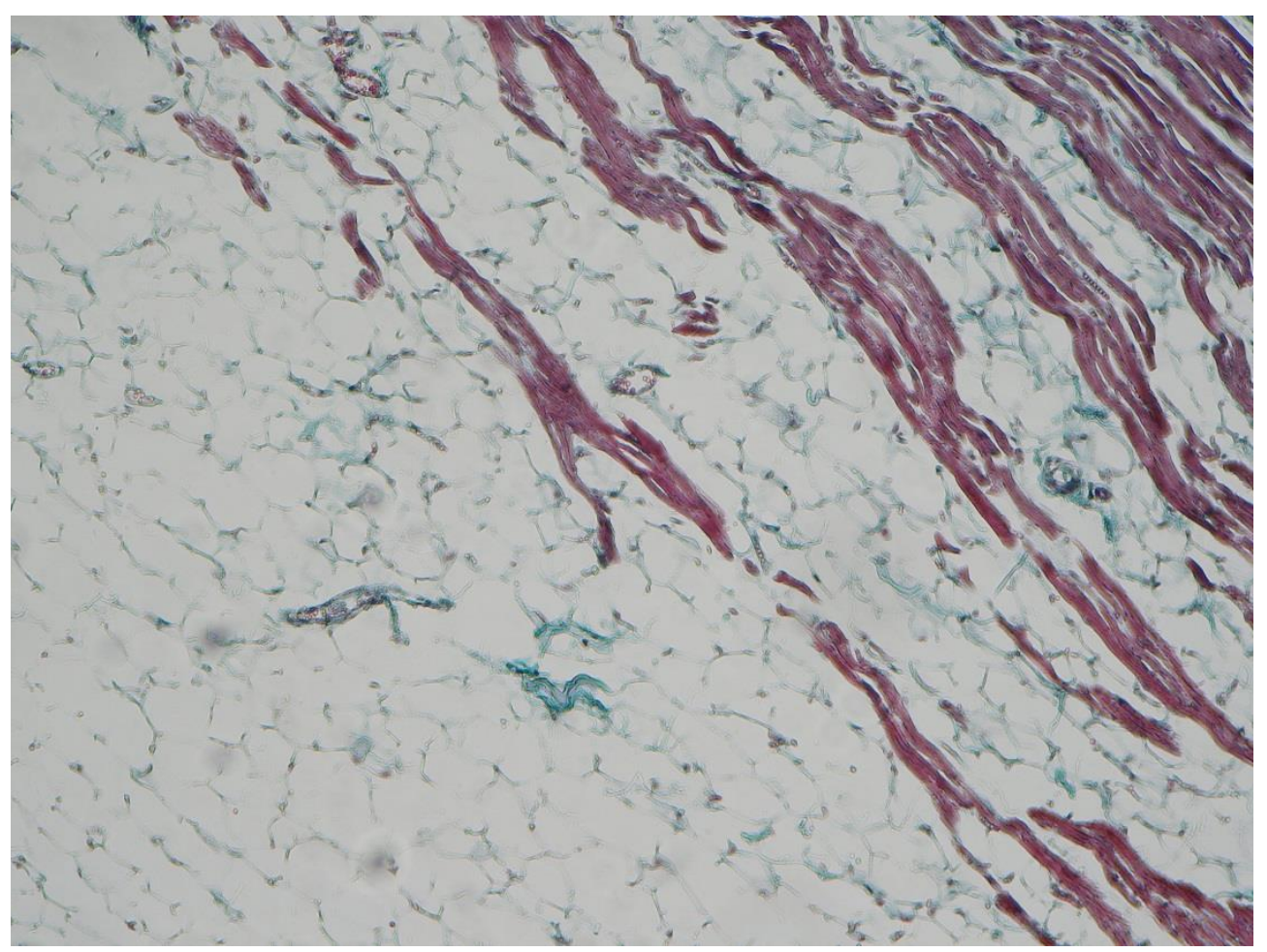

Fig. 2. Myocardium appearance in ARVC with progressive fibro-adipose replacement of myocardium initiated from epicardium (Masson's trichrome, 40x) 


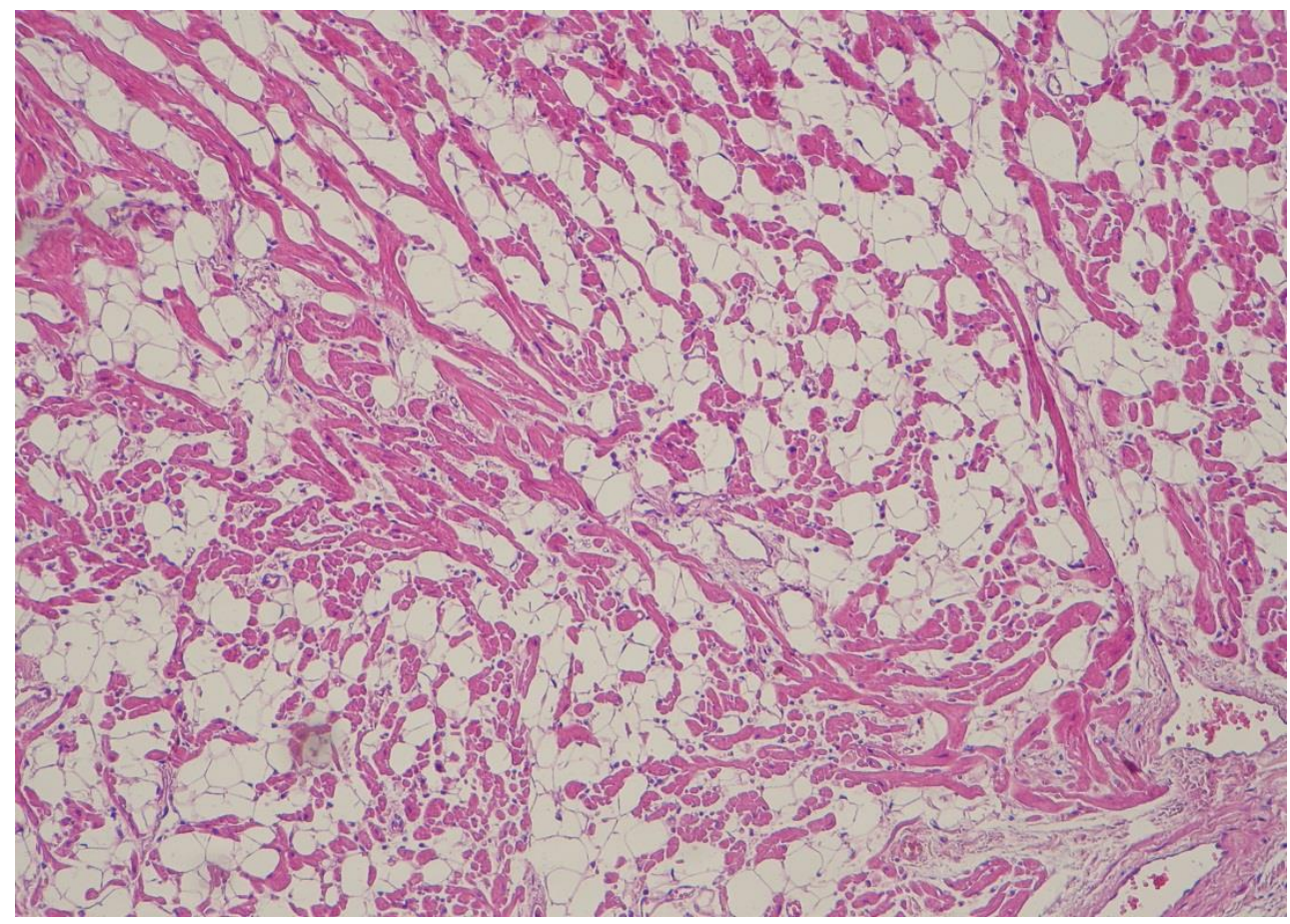

Fig. 3. Fibro-adipose replacement of myocardium (HE, 40x)

\section{Diagnosis and differentials}

A scoring system is currently used to facilitate the diagnosis, namely the Task Force Criteria (TFC), a system proposed by McKenna and co-workers, in 1994, later revised by Marcus and co-workers, in 2010 (Table 2) [43, 45].

Using this score, a specific value is attributed to family history, clinical imaging, electrocardiography, and molecular genetic testing [43]. A patient having two major criteria, or one major criterion and two minor criteria, or four minor criteria is diagnosed with ARVC. Patients having either one major criterion and one minor criterion or three minor criteria are considered as suspicious for diagnosis. The diagnosis is excluded in patients having only one major or two minor criteria [1].

The endomyocardial biopsy may be performed in cases were non-invasive paraclinical investigations are not conclusive.

However, the endomyocardial biopsies are frequently fals negative, as ARVC is initiated in subepicardial areas and has a slow progression towards endocardium, so the subendocardial areas used to collect tissular fragment may not be yet involved. Moreover, the biopsies are usually done from the interventricular septum, an area which is frequently unaffected. Not the last, the disease may be focal, and the presence of fibroadipose tissue in myocardium is not a specific marker of the disease, as it may also occur in ischemic cardiomyopathy $[1,18]$.

In order to increase biopsy accuracy, the collection should be achieved from the right ventricle free wall, but this would increase the risk of cardiac tamponade.

However, myocardial endobiopsy remains the diagnosis invasive method, the general indication being to collect the fragment from the "triangle of dysplasia", an area between the apex, infundibulum, and posteroinferior wall. The biopsies from septae or left ventricle are not useful for diagnosis $[1,20]$.

Nowadays, an important value in diagnosis and screening is attributed to genetic testing, though a negative result cannot exclude ARVC diagnosis [29].

A supplementary criterion to support the diagnosis is also the therapeutic response to isoproterenol, as intravenous administration of very high dose $(45 \mathrm{mcg} / \mathrm{min})$, for $3 \mathrm{~min}[46$, 47]. ECG is continuously registered during the 
test and 10 minutes after the administration of this drug, the test being positive if polymorphic PVCs ( $>3$ morphologies) and if at least one couplet is observed [46, 47].

The differentials in ARVC include a multitude of heart diseases, such as: conventional dilatative cardiomyopathy, right- sided sarcoidosis, myocarditis, and idiopathic arrhythmias. As a differential from dilatative cardiomyopathy, discordance between arrhythmias severity and ventricular disfunction is noticed in ARVC, a feature that facilitates the differential diagnosis.

Table 2. The Task Force Criteria in ARVC/D - 2010

\begin{tabular}{|c|c|c|}
\hline Categories & Major criteria & Minor criteria \\
\hline \multirow{5}{*}{$\begin{array}{l}\text { Global or } \\
\text { regional } \\
\text { dysfunction and } \\
\text { structural } \\
\text { alterations }\end{array}$} & By 2D echo: & By 2D echo: \\
\hline & $\begin{array}{l}\text { Regional RV akinesia, dyskinesia or aneurysm } \\
\text { By MRI: }\end{array}$ & $\begin{array}{l}\text { Regional RV akinesia or dyskinesia } \\
\text { By MRI: }\end{array}$ \\
\hline & $\begin{array}{l}\text { Regional RV akinesia, dyskinesia or } \\
\text { dyssynchronous RV contraction and } 1 \text { of the } \\
\text { following: }\end{array}$ & $\begin{array}{l}\text { Regional RV akinesia, dyskinesia or } \\
\text { dyssynchronous RV contraction and } 1 \text { of } \\
\text { the following: }\end{array}$ \\
\hline & $\begin{array}{l}\text { Ratio of } R V \text { end-diastolic volume to } \\
\mathrm{BSA} \geq 110 \mathrm{~mL} / \mathrm{m}^{2} \text { (male) or } \geq 100 \\
\mathrm{~mL} / \mathrm{m}^{2} \text { (female) } \\
\text { - } \quad \text { RV ejection fraction } \leq 40 \%\end{array}$ & $\begin{array}{l}\text { Ratio of } R V \text { end-diastolic } \\
\text { volume to } B S A \geq 100 \text { to }<110 \\
\mathrm{~mL} / \mathrm{m}^{2} \text { (male) or } \geq 90 \text { to }<100 \\
\mathrm{~mL} / \mathrm{m}^{2} \text { (female) }\end{array}$ \\
\hline & $\begin{array}{l}\text { By RV angiography: } \\
\text { Regional RV akinesia, dyskinesia or aneurysm }\end{array}$ & $\begin{array}{l}\text { RV ejection fraction }>40 \% \text { to } \\
\leq 45 \%\end{array}$ \\
\hline $\begin{array}{l}\text { Tissue } \\
\text { characterization } \\
\text { of the wall }\end{array}$ & $\begin{array}{l}\text { Residual myocytes }<60 \% \text { by morphometric } \\
\text { analysis (or }<50 \% \text { if estimated) with fibrous } \\
\text { replacement of the RV free wall myocardium in } \\
\geq 1 \text { sample, with or without fatty replacement of } \\
\text { tissue on endomyocardial biopsy }\end{array}$ & $\begin{array}{l}\text { Residual myocytes } 60 \% \text { to } 75 \% \text { by } \\
\text { morphometric analysis (or } 50 \% \text { to } 65 \% \text { if } \\
\text { estimated) with fibrous replacement of } \\
\text { the RV free wall myocardium in } \geq 1 \\
\text { sample, with or without fatty replacement } \\
\text { of tissue on endomyocardial biopsy }\end{array}$ \\
\hline $\begin{array}{l}\text { Repolarization } \\
\text { abnormalities }\end{array}$ & $\begin{array}{l}\text { Inverted T waves in right precordial leads (V1, } \\
\text { V2, and V3) or beyond in individuals }>14 \text { years } \\
\text { of age (in the absence of complete right } \\
\text { bundle-branch block } Q R S \geq 120 \mathrm{~ms} \text { ) }\end{array}$ & $\begin{array}{l}\text { Inverted T waves in leads V1 and V2 in } \\
\text { individuals }>14 \text { years of age (in the } \\
\text { absence of complete right bundle-branch } \\
\text { block) or in V4, V5, or V } 6 \\
\text { Inverted T waves in leads V1, V2, V3, } \\
\text { and V4 in individuals }>14 \text { years of age in } \\
\text { the presence of complete right bundle- } \\
\text { branch block }\end{array}$ \\
\hline $\begin{array}{l}\text { Depolarization/ } \\
\text { conduction } \\
\text { abnormalities }\end{array}$ & $\begin{array}{l}\text { Epsilon wave (reproducible low-amplitude } \\
\text { signals between end of QRS complex to onset } \\
\text { of the T wave) in the right precordial leads (V1 } \\
\text { to V3) }\end{array}$ & $\begin{array}{l}\text { Late potentials by SAECG in } \geq 1 \text { of } 3 \\
\text { parameters in the absence of a QRS } \\
\text { duration of } \geq 110 \mathrm{~ms} \text { on the standard } \\
\text { ECG }\end{array}$ \\
\hline Arrhythmias & $\begin{array}{l}\text { Nonsustained or sustained ventricular } \\
\text { tachycardia of left bundle-branch morphology } \\
\text { with superior axis (negative or indeterminate } \\
\text { QRS in leads II, III, and aVF and positive in } \\
\text { lead aVL) }\end{array}$ & $\begin{array}{l}\text { Nonsustained or sustained ventricular } \\
\text { tachycardia of RV outflow configuration, } \\
\text { left bundle-branch block morphology with } \\
\text { inferior axis (positive QRS in leads II, III, } \\
\text { and aVF and negative in lead aVL) or of } \\
\text { unknown axis } \\
>500 \text { ventricular extrasystoles per } 24 \\
\text { hours (Holter) }\end{array}$ \\
\hline Family history & $\begin{array}{l}\text { ARVC confirmed pathologically at autopsy or } \\
\text { surgery } \\
\text { Identification of a pathogenic mutation } \\
\text { categorized as associated or probably } \\
\text { associated with ARVC in the patient under } \\
\text { evaluation }\end{array}$ & $\begin{array}{l}\text { Premature sudden death ( }<35 \text { years of } \\
\text { age) due to suspected ARVC in a first- } \\
\text { degree relative }\end{array}$ \\
\hline
\end{tabular}

Right ventricle (RV), Electrocardiography (ECG), Signal-averaged electrocardiography (SAECG) 
Clinical manifestations are similar in rightsided sarcoidosis, but there is characteristic involvement of the interventricular septum and atrioventricular arrhythmias, while they are rare in ARVC. Furthermore, specific granulomatous inflammation evidentiated in microscopy settles the differential diagnosis.

Differential with viral myocarditis is difficult, mononuclears being evident in both microscopic specimens. Serological and genetic tests may be, in this case, useful for differential diagnosis.

\section{Perspectives}

As the causative genes for ARVC have been identified, the premises of populational screening are met. The Sanger method represents the gold standard of sequencing, with two times of PCR applied for target exons [11]. Due to long time and high costs, next generation sequencing (NGS) methods are currently developed, being usefull in whole genome, exon, or target gene sequencing [11]. With the currently available panels for genetic analysis, ARVC can be detected in a week [11].

Unfortunately, causative mutations are difficult to distinguish from other genetic noise [48]. In order to eliminate the genetic noise, data for ethnically matched controls is

\section{References}

1. McGregor SM, Husain AN. A Brief Review and Update of the Clinicopathologic Diagnosis of Arrhythmogenic Cardiomyopathy. Arch Pathol Lab Med 2015; 139(9):1181-1186.

2. Segall HN. Parchment heart (Osler). Am Heart J 1950; 40(6):948-950.

3. Uhl HS. A previously underscribed congenital malformation of the heart: Almost total absence of the myocardium of the right ventricle. Bull Johns Hopkins Hosp 1952; 91:197-209.

4. Marcus FI, Fontaine GH, Guiraudon G, et al. Right ventricular dysplasia: a report of 24 adult cases. Circulation 1982; 65(2):384-398.

5. Gerlis LM, Schmidt-Ott SC, Ho SY, et al. Dysplastic conditions of the right ventricular myocardium: Uhl's anomaly vs arrhythmogenic right ventricular dysplasia. $\mathrm{Br}$ Heart $J$ 1993; 69(2):142-150. necessary, associated with special softwares for prediction of pathogenic mutations to evaluate the genetic result of a patient [49]. Furthermore, the compatibility with the phenotype of the disease is needed in order to validate the genetic result [11].

\section{Conclusions}

ARVC is a genetic disease with vital prognosis determined in a majority of cases by gene mutations. Patients have severe ventricular arrhythmias, syncope, and sudden death risk.

Light microscopy allows the observation of fibro-adipose tissue progressively replacing the right ventricular wall myocardium.

Due to the tremendous progress in elucidating the genetic determinism of ARVC, genetic testing may be used as a populational screening and premises of possible practical applications in therapy may prevent sudden cardiac death in young people.

\section{Conflict of interest}

The authors declare that they have no competing interests.

6. Protonotarios N, Tsatsopoulou A, Patsourakos $P$, et al. Cardiac abnormalities in familial palmoplantar keratosis. Br Heart $J$ 1986; 56(4):321-326.

7. Rampazzo A, Nava A, Malacrida $S$, et al. Mutation in human desmoplakin domain binding to plakoglob in causes a dominant form of arrhythmogenic right ventricular cardiomyopathy. Am J Hum Genet 2002; 71(5):1200-1206.

8. McKenna WJ, Thiene G, Nava A, et al. Diagnosis of arrhythmogenic right ventricular dysplasia cardiomyopathy. Br Heart J 1994; 71(3):215-218.

9. Marcus FI, McKenna WJ, Sherrill D, et al. Diagnosis of arrhythmogenic right ventricular cardiomyopathy/dysplasia: proposed modification of the task force criteria. Circulation 2010; 121(13):1533-1541. 
10. Ross MH, Pawlina W. Histology: a Text and Atlas: with correlated cell and molecular biology. 7th edition. Wolters Kluwer, 2015.

11. Ohno S. The genetic background of arrhythmogenic right ventricular cardiomyopathy. J Arrhythm 2016; 32(5):398403.

12. Orgeron GM, Calkins $H$. Advances in the Diagnosis and Management of Arrhythmogenic Right Ventricular Dysplasia/Cardiomyopathy. Curr Cardiol Rep 2016; 18(6):53.

13. Lahtinen $A M$, Lehtonen $E$, Marjamaa $A$, et al. Population-prevalent desmosomal mutations predisposing to arrhythmogenic right ventricular cardiomyopathy. Heart Rhythm 2011; 8(8):1214-1221.

14. Francés RJ. Arrhythmogenic right ventricular dysplasia/cardiomyopathy. A review and update. Int J Cardiol 2006; 110(3):279-287.

15. Thiene G, Corrado D, Basso C. Arrhythmogenic right ventricular cardiomyopathy/dysplasia. Orphanet $J$ Rare Dis 2007; 14(2):45.

16. Tabib A, Loire $R$, Chalabreysse $L$, et al. Circumstances of death and gross and microscopic observations in a series of 200 cases of sudden death associated with arrhythmogenic right ventricular cardiomyopathy and/or dysplasia. Circulation 2003; 108(24):3000-3005.

17. Butcovan D, Amalinei C, Grigoriu C. Arrhythmogenic right ventricular cardiomyopathy - cause of sudden death in young people. Rom J Leg Med 2011; 19:189194.

18. Azaouagh A, Churzidse S, Konorza $T$, et al. Arrhythmogenic right ventricular cardiomyopathy/dysplasia: a review and update. Clin Res Cardiol 2011; 100(5):383394.

19. Groeneweg J, Bhonsale A, James $C$, et al. Clinical presentation, long-term follow-up, and outcomes of 1001 arrhythmogenic right ventricular dysplasia/cardiomyopathy patients and family members. Circ Cardiovasc Genet 2015; 8(3):437-446.

20. Calkins $H$. Arrhythmogenic right ventricular dysplasia/cardiomyopathy-three decades of progress. Circ J 2015; 79(5):901-913.

21. Dalal D, Nasir K, Bomma $C$, et al. Arrhythmogenic right ventricular dysplasia: a United States experience. Circulation 2005; 112(25):3823-3832.

22. Murray B. Arrhythmogenic right ventricular dysplasia/cardiomyopathy (ARVD/C): a review of molecular and clinical literature. J Genet Couns 2012; 21(4):494-504.
23. McKoy G, Protonotarios N, Crosby A, et al. Identification of a deletion in plakoglobin in arrhythmogenic right ventricular cardiomyopathy with palmoplantar keratoderma and woolly hair (Naxos disease). Lancet 2000; 355(9221):2119-2124.

24. Norgett EE, Hatsell SJ, Carvajal-Huerta L, et al. Recessive mutation in desmoplakin disrupts desmoplakin-intermediate filament interactions and causes dilated cardiomyopathy, woolly hair and keratoderma. Hum Mol Genet 2000; 9(18):1276-2761.

25. Te Riele AS, Hauer RN. Arrhythmogenic right ventricular dysplasia/cardiomyopathy: clinical challenges in a changing disease spectrum. Trends Cardiovasc Med 2015; 25(3):191-198.

26. Orgeron GM, Crosson JE. Arrhythmogenic right ventricular dysplasia/cardiomyopathy. Cardiol Young 2017; 27(S1):S57-S61.

27. Zareba W. Quantifying Disease Progression in Arrhythmogenic Right Ventricular Dysplasia/Cardiomyopathy: Key to Advancing Therapy. JAMA Cardiol 2017; 11.

28. Bhuiyan ZA, Jongbloed JD, van der Smagt J, et al. Desmoglein-2 and desmocollin-2 mutations in Dutch arrhythmogenic right ventricular dysplasia/cardiomypathy patients: results from a multicenter study. Circ Cardiovasc Genet 2009; 2(5):418-427.

29. Kapplinger JD, Landstrom AP, Salisbury BA, et al. Distinguishing arrhythmogenic right ventricular cardiomyopathy/dysplasiaassociated mutations from background genetic noise. J Am Coll Cardiol 2011; 57(23):23172327.

30. Bhonsale A, Groeneweg JA, James CA. Impact of genotype on clinical course in arrhythmogenic right ventricular dysplasia/cardiomyopathy-associated mutation carriers. Eur Heart J 2015; 36(14):847-855.

31. Rigato I, Bauce B, Rampazzo A, et al. Compound and digenic heterozygosity predicts life-time arrhythmic outcome and sudden cardiac death in desmosomal gene-related arrhythmogenic right ventricular cardiomyopathy. Circ Cardiovasc Genet 2013; 6(6):533-542.

32. Vanderschuren $\mathrm{KL}$, Sieverink $\mathrm{T}$, Wilders $\mathrm{R}$. Arrhythmogenic right ventricular dysplasia/cardiomyopathy type 1: a light on molecular mechanisms. Genet Res Int 2013; 2013:460805.

33. Rampazzo A, Nava A, Danieli GA, et al. The gene for arrhythmogenic right ventricular cardiomyopathy maps to chromosome 14q23q24. Hum Mol Genet 1994; 3(6):959-962.

34. Beffagna $G$, Occhi $G$, Nava $A$, et al. Regulatory mutations in transforming growth factor- $\beta 3$ 
gene cause arrhythmogenic right ventricular cardiomyopathy type 1. Cardiovasc Res 2005; 65(2):366-373.

35. Basso C, Thiene G, Corrado D, et al. Arrhythmogenic right ventricular cardiomyopathy: dysplasia, dystrophy, or myocarditis? Circulation 1996; 94(5):983-999.

36. Asimaki A, Tandri $H$, Duffy ER, et al. Altered desmosomal proteins in granulomatous myocarditis and potential pathogenic links to arrhythmogenic right ventricular cardiomyopathy. Circ Arrhythm Electrophysiol 2011; 4(5):743-752.

37. Campuzano $O$, Alcalde $M$, Iglesias $A$, et al. Arrhythmogenic right ventricular cardiomyopathy: severe structural alterations are associated with inflammation. J Clin Pathol 2012; 65(12):1077-1783.

38. Calabrese F, Basso C, Carturan E, et al. Arrhythmogenic right ventricular cardiomyopathy/dysplasia: is there a role for viruses? Cardiovasc Pathol 2006; 15(1):11-17.

39. Bowles NE, Ni J, Marcus F, et al. The detection of cardiotropic viruses in the myocardium of patients with arrhythmogenic right ventricular dysplasia/cardiomyopathy. J Am Coll Cardiol 2002; 39(5):892-895.

40. Garcia-Gras E, Lombardi R, Giocondo MJ, et al. Suppression of canonical Wnt/beta-catenin signaling by nuclear plakoglobin recapitulates phenotype of arrhythmogenic right ventricular cardiomyopathy. J Clin Invest 2006; 116(7):2012-2021.

41. Philips B, Cheng A. 2015 update on the diagnosis and management of arrhythmogenic right ventricular cardiomyopathy. Curr Opin Cardiol 2016; 31(1):46-56.

42. Roberts WC, Ko JM, Kuiper JJ, et al. Some previously neglected examples of arrhythmogenic right ventricular dysplasia/cardiomyopathy and frequency of its various reported manifestations. Am J Cardiol 2010; 106(2):268-274.

43. Marcus FI, McKenna WJ, Sherrill D, et al. Diagnosis of arrhythmogenic right ventricular cardiomyopathy/dysplasia: proposed modification of the Task Force Criteria. Eur Heart J 2010; 31(7):806-814.

44. Asimaki $A$, Tandri $H$, Huang $H$, et al. A new diagnostic test for arrhythmogenic right ventricular cardiomyopathy. $N$ Engl J Med 2009; 360(11):1075-1084.

45. McKenna WJ, Thiene G, Nava A, et al. Diagnosis of arrhythmogenic right ventricular dysplasia/cardiomyopathy. Task Force of the Working Group Myocardial and Pericardial Disease of the European Society of Cardiology and of the Scientific Council on Cardiomyopathies of the International Society and Federation of Cardiology. Br Heart J 1994; 71(3):215-218.

46. Philips B, Madhavan S, James C, et al. High prevalence of catecholamine-facilitated focal ventricular tachycardia in patients with arrhythmogenic right ventricular dysplasia/cardiomyopathy. Circ Arrhythm Electrophysiol 2013; 6(1):160-166.

47. Denis A, Sacher F, Derval N, et al. Diagnostic value of isoproterenol testing in arrhythmogenic right ventricular cardiomyopathy. Circ Arrhythm Electrophysiol 2014; 7(4):590-597.

48. Kapplinger JD, LandstromAP, Salisbury BA, et al. Distinguishing arrhythmogenic right ventricular cardiomyopathy/dysplasiaassociated mutations from background genetic noise. J Am Coll Cardiol 2011; 57(23):23172327.

49. Kircher M, Witten DM, Jain $\mathrm{P}$, et al. A general framework for estimating the relative pathogenicity of human genetic variants. Nat Genet 2014; 46(3):310-315. 